\title{
Anti-gender politics and the authoritarian turn in Brazil ${ }^{1}$
}

\author{
Gustavo Gomes da Costa Santos
}

\begin{abstract}
In 2018, Jair Bolsonaro, a former captain and congressman known for his racist, sexist, and homophobic remarks, was elected president of Brazil. His election shocked political analysts, representing the most significant setback for Brazilian democracy since the end of military rule in the 1980s. The present work analyses the social actors and political processes behind Bolsonaro's rise to power, focusing on the role of anti-gender politics in the recent authoritarian turn in Brazil. Borrowing insights from social movement literature, the article explores the dynamics of anti-gender protest events, their main social and political actors, and repertoires of actions and demands. It also reviews the recent debate on the crisis of democracy and the rise of extreme right-wing movements and parties, focusing on the centrality of opposition to gender equality and LGBTQI+ rights in the rhetoric and action of conservative and far-right groups.
\end{abstract}

\section{Resumo}

Em 2018, Jair Bolsonaro, ex-capitão e deputado conhecido por seus comentários racistas, sexistas e homofóbicos, foi eleito presidente do Brasil. Sua eleição chocou analistas políticos, representando o maior retrocesso na democracia brasileira desde o fim do regime militar nos anos 80. O presente trabalho analisa os atores sociais e os processos políticos que viabilizaram a ascensão de Bolsonaro ao poder, concentrando-se no papel das políticas anti-gênero na recente virada autoritária no Brasil. Inspirado em alguns insights da literatura sobre movimentos sociais, o trabalho explora a dinâmica dos eventos de protesto anti-gênero, seus principais atores sociais e políticos, repertórios de ações e demandas. Também analisa o recente debate sobre a crise da democracia e o avanço de movimentos e partidos de extrema direita, centrando-se na centralidade da oposição à igualdade de gênero e aos direitos LGBTQI + na retórica e na ação destes movimentos.

\footnotetext{
${ }^{1}$ This article is part of the CAGE project (Anti-gender campaigns in Europe), funded by the Agence Universitaire de la Francophonie (AUF).
} 
In October 2018, Jair Bolsonaro, a former captain and congressman known for his racist, sexist, and homophobic remarks, was elected president of Brazil. His election shocked political analysts across the world. Until then, Brazil had been considered a case of successful democratic consolidation. For 30 years, the country experienced peaceful rotation of power between centre-right and centre-left political forces and a steady, although modest, reduction of social inequalities. As a world-known publication stated in 2009, Brazil was "taking off" (The Economist, 2009) and on a trajectory of economic prosperity and social justice. However, this scenario has started to change dangerously in recent years. In June 2013, Brazil was shaken by multitudinous demonstrations all over the country. The so-called "June Journeys" changed Brazilian political landscape dramatically, leading to a long period of political instability.

Bolsonaro's campaign was based on a strong anti-politics rhetoric, articulating a widespread anti-Worker's Party sentiment (antipetismo), a rejection of corrupt political elites, and opposition to many of the "new left agendas", particularly blacks, women, LGBTQI+ and indigenous people's rights, and environmentalism. The opposition to gender equality and sexual diversity was crucial to this articulation, particularly in engaging evangelical and catholic constituencies in Bolsonaro's campaign. It largely used images and symbols that portrayed feminists and LGBTQI+ activists as morally corrupt, engaged in a war against God, the family, and the nation.

The present work aims to analyse the social actors and the political processes behind the recent authoritarian turn in Brazilian politics represented by Bolsonaro's rise to power. It focuses on the role of anti-gender politics (Kunhar and Paternotte, 2017) in this authoritarian turn, particularly the recent engagement of extreme-right groups and individuals that opposed the agenda of sexual and reproductive rights.

Bolsonaro's election can be considered part of a recent rise of the extreme-right to power in different parts of the world. Although the rise of the extreme-right depends heavily on national contexts, one can identify certain common and transnational trends, such as the negative effects of the 2008 economic crisis which led to the current crisis of representative democracy. This crisis took place at a moment of increasing public visibility of the so-called sexual minorities across a number of countries (including Brazil), demanding (with different levels of success) the recognition of their identities and rights. The public visibility of sexual minorities has largely been used by extreme-right populist 
leaders, such as Bolsonaro, as the symbol of a perceived threat to certain social groups, helping to galvanize the articulation of different (and sometimes antagonistic) demands around an authoritarian extreme-right agenda.

Borrowing insights from the literature on social movements, particularly from studies focusing on right-wing social movements, the present work explores the dynamics of anti-gender politics in Brazil, highlighting key social and political actors, their collective repertoires of action, their demands, and their objectives. To do so, the work analyses newspaper articles relating to anti-gender politics published between 2011 and 2018, in the Folha de S. Paulo, Brazil's most widely circulated newspaper. It employs the Protest Event Analysis (PEA) methodology.

The article is organized as follows: in the first section, I briefly introduce the recent debate on the crisis of democracy and the expansion of extreme right-wing movements and parties to identify broader transnational processes surrounding the Brazilian context. In the second section, I address the advancement of the anti-gender agenda and the extreme-right, focusing on the centrality of opposition to gender equity and LGBTQI+ rights in the rhetoric and action of conservative and far-right groups. In the third section, I briefly review the literature dealing with conservative and far-right social movements. In the fourth section, I present a description of the methodology for collecting and analysing empirical data, exploring its limitations as well as the possibilities it opens to understanding anti-gender politics in Brazil. In the fifth section, I analyse the empirical data, exploring the evolution of anti-gender protest events, the main individuals and social actors engaged in them, their level of participation, repertoires of action, objectives, and claims. Finally, I present some closing remarks, highlighting the role of the anti-gender agenda in the election of Bolsonaro in Brazil and reflecting on the extent to which the Brazilian experience helps us to understand broader social and political processes in the contemporary world.

\section{The crisis of democracy and the rise of the extreme right in the contemporaneity}

The crisis of democracy is one of the most widely discussed topics of contemporary social sciences. Scholars have been looking at its causes, meanings, and consequences, arriving at different, sometimes even contradictory, diagnoses. There is, however, a relative consensus regarding the centrality of the 2008 global crisis of capitalism in triggering the current political crisis (Castells, 2018). Decades of neoliberal policies resulted in the dismantling of social protection networks in several countries, placing vast population 
groups in a situation of extreme vulnerability to the cyclical crises of capitalist globalization (Przeworski, 2019).

In the post-2008 context, the very foundations of representative democracy have come under criticism (Brown, 2019; Norris and Inglehart, 2019). Political parties, parliaments, elections, and other mechanisms of democratic representation have had their effectiveness put in check. The drastic reduction in political party membership, the decreasing participation of the population in elections, and a generalized distrust in the political class and institutions of representation (Foa and Mounk, 2017; Przeworski, 2019) have intensified, leading many analysts to envision a pessimistic scenario (Castells, 2018; Levitsky and Ziblatt, 2018) in which liberal representative democracy would no longer be able to channell social conflicts and guarantee citizenship rights for most of the population.

In response to the 2008 economic crisis, new social movements have emerged, criticizing the mechanisms of liberal political representation and demanding the deepening of democracy through the expansion of citizen participation. (Zizek, 2015; Pleyers, 2018; Pinheiro-Machado, 2019). It is in this context that extreme right movements rose in Europe and in the US (Skocpol and Williamson, 2016; Norris and Inglehart, 2019). While sharing many of the criticisms of representative democracy advocated by "progressive" movements, such as distrust in the political class and the ineffectiveness of representative institutions in responding to popular demands, extreme right movements have brought a strongly antidemocratic political agenda to the public sphere. Immigrants and asylum seekers, Jews, Afro-descendants, feminists, LGBTQI+, environmentalists, and the "left" appear in the speeches of the right-wing groups as those responsible for the deterioration of the population's living conditions. The exclusion of those groups from the democratic "demos" is regarded by right-wing groups as the only way to restore national order and prosperity (Wodak, 2015; Fassin, 2017; Traverso, 2019).

Although the 2008 crisis of global capitalism helps us to understand the transnational dimension of the current crisis of democracy, it does not allow us to understand the particularities of different regional and national contexts. In Europe, for example, the European Union's inability to handle the 2015 migrant crisis had such a decisive symbolic impact that the rhetoric of far-right groups was echoed across various social groups (especially in the local working classes), who were dissatisfied with their loss of status and worsening quality of life (Traverso, 2019; Fassin, 2017). Several party organizations began to publicly defend racist, ethnocentric, misogynistic, and homophobic agendas, achieving expressive electoral results. In France and Germany, extreme right parties such as the then- 
National Front (FN) and Alternative for Germany (AfD) parties obtained significant votes supporting a conservative, Eurosceptic, and anti-immigration agenda (Wodak, 2015; Traverso, 2019).

In the US, Barack Obama's election, the first black president in the history of the country, and the greater visibility of the so-called "social minorities" contributed to the radicalisation of conservative sectors among the low-income and low-educated white population, particularly affected by the 2008 crisis (Norris and Inglehart, 2019). The "Tea Party" movement (Skocpol and Williamson, 2016) demonstrated a strong capacity for mobilising conservative sectors around a White, Anglo-Saxon, Protestant (WASP) ethnonationalism which opposed abortion, same-sex marriage, and immigration. The election of Donald Trump was strongly influenced by the mobilization of the extreme right, and intensified political polarization (Norris and Inglehart, 2019).

The rise of conservative and right-wing groups has also been observed in Latin America and Brazil (Velasco Cruz et al, 2015; Solano, 2018; Pinheiro-Machado, 2019), but with some important distinctions. The first particularity refers to these groups' lack of public presence during the 1980s and 1990s. Their proximity to former dictatorial governments resulted in their being highly criticized by society (Luna and Kaltwasser, 2014). In the Brazilian case, even conservative politicians rejected the terms "conservative" or "rightwing", which some authors refer to as the "shamed right" (direita envergonhada) (Rodrigues, 1987; Mainwaring et al., 2000; Quadros and Madeira, 2018). The second distinctive feature is the weakness (or even non-existence) of political parties that clearly identify with Latin America's right-wing values and agendas. The weak organization of the right does not mean its political and institutional weakness. Luna and Kaltwasser (2014) and Eaton (2014) point out that the right has had relative success in securing positions of power in postdemocratisation political institutions, preventing the implementation of redistributive policies that would jeopardize elite interests.

This context changed considerably at the beginning of the 21st century, with the election of left and centre-left governments across the region (Chase-Dunn et al., 2015; Weyland et al., 2010). They proposed the expansion of social spending, a greater presence of the State as an inducer of economic growth, and criticized the negative effects of the neoliberal, pro-market policies of the 1980s and 1990s. The "commodity boom" generated by China's growth (Weyland et al., 2010; Singer, 2012) made it possible for these governments to expand social spending and domestic consumer markets, resulting in some reduction of social inequalities. 
These measures did not prevent the negative consequences of the 2008 crisis arriving in Latin America. High inflation rates and the devaluation of local currencies affected not only the working classes, but also the urban middle classes (Singer, 2018), intensifying criticisms against "progressive" governments and contributing to the reorganization of conservative groups. In Paraguay, Fernando Lugo's centre-left government was overthrown by a parliamentary coup orchestrated by conservative and right-wing sectors in 2012 (Szwako, 2014). In Argentina and Chile, the centre-right managed to return to power through elections in 2015 and 2010, respectively. In Brazil, conservative and far-right sectors organised broad social mobilisations demanding the impeachment of President Dilma Rousseff between 2015 and 2016 (Velasco Cruz et al., 2015). These mobilisations had broad support from the media, as well as economic and political elites, resulting in the dismissal of President Rousseff in 2016, in a controversial impeachment process denounced by various sectors of society as a "parliamentary coup" (Avrizter, 2019).

\section{Anti-gender politics and the rise of the extreme-right}

The crisis of democracy and the advance of the extreme right have unfolded in a context of increasing visibility of black Brazilians, women, LGBTQI+ and indigenous peoples, which demanded specific policies to address historical injustices. The visibility and the extension of rights to these groups have questioned, directly or indirectly, certain values and traditions rooted in society. Some social groups perceived the positive visibility of the so-called "minorities" as a threat to their existence as a community (Fukuyama, 2018). Farright political leaders have been cultivating the feeling of fear and threat (Wodak, 2015) in public opinion inciting the antagonism between us ("the good citizen", "the Christians", "the Europeans") and the "others" ("immigrants", "Muslims", "feminists", "LGBTQI+" etc.). In such a scenario, there is no room for compromise and the "solution" of the political conflict necessarily passes through the (symbolic or physical) exclusion of this "other" from the political community (Traverso, 2019; Fassin, 2017).

Depending on the national context, the social group chosen as the "scapegoat" can vary. However, feminist and LGBTQI + rights activists seems to be seen as the threating "other" in social and political contexts as heterogeneous as the US, Latin America, and Europe (Dietze and Roth, 2020). To understand the centrality of opposition to feminist and LGBTQI+ activism in the rhetoric of conservative and far-right actors, one must analyse the transformations experienced by the reproductive and sexual rights agenda over the last few decades. This agenda has progressed in several countries, as well as in international forums 
since the 1990s. The United Nations' conferences of women in Beijing (1994) and the population of Cairo (1996) brought women's rights to the centre of debates about human rights (Corrêa, Petchesky and Parker, 2008). An important novelty of both conferences was the incorporation of the concept of gender in international initiatives to promote equality between men and women (Corrêa and Petchesky, 1996). The concept made it possible to incorporate the dimension of sexuality, expanding the scope of protection of human rights by including the right to abortion and the rights of the LGBTQI+ population (Corrêa, 2018). Simultaneously, laws expanding sexual and reproductive rights, such as anti-discrimination and pro-choice laws and the recognition of same-sex unions, were passed in several European countries (Temblay et al., 2011), as well as in Latin America (Corrêa and Parker, 2011).

The Catholic Church has played a leading role in the opposition to sexual and reproductive rights in the international sphere (Corrêa, 2018). In Brazil, as in other Latin American countries, the Catholic Church has shared this role with another important social actor: the evangelical churches, particularly the neo-Pentecostal denominations (Gomes da Costa, 2019). Despite the hegemony of religious actors in the opposition to sexual and reproductive rights, these issues have always been, to a greater or lesser extent, on the agendas of other conservative and right-wing groups (Kunhar and Paternotte, 2017; Prado and Corrêa, 2018). The defence of religious values and social hierarchies have always been central to the extreme right (Wodak, 2015; Traverso, 2019). The ethnonationalism defended by far-right movements and parties is often linked to religious values and metaphors, such as the assumption of an organic national community structured similarly to the "natural family" (Dietze and Roth, 2020). This notion of family is anchored in heteronormative assumptions, in which gender inequalities are perceived as part of the "natural order" and expressions of sexuality not conforming with heterosexuality are seen as "sinful" and "threats" to the existence of the nation (Mudde, 2020).

In Brazil, the election of Luís Inácio Lula da Silva, from the Worker's Party, in 2003, was a milestone in the promotion of sexual and reproductive rights. Historical demands from the feminist and LGBTQI+ movements turned into a "government issue" (Gomes da Costa, 2016). In 2003, Lula da Silva's administration created a secretariat to coordinate gender equality policies (Secretaria de Políticas das Mulheres). In 2004, it implemented the "Brazil without homophobia" (Brasil sem homofobia), the first nation-wide policy in Latin America specifically focused on the promotion of LGBT rights. In 2011, the Brazilian Supreme Court ruled in favour of recognising same-sex unions nationwide, followed in 2012 by a ruling which widened the right to abortion in cases of fetuses with anencephaly. 
Contrary to executive and judiciary initiatives, the agenda of sexual and reproductive rights was blocked by religious congressmen in the legislative, mostly members of the evangelical caucus who were part of the governmental coalition (Gomes da Costa, 2019). The suspension of the distribution of the material "School without homophobia" in 2011, the approval of the bill legalizing conversion therapies (called the "gay cure") in 2013 and the exclusion of the terms "gender equity" and "sexual orientation" of the National Education Plan in 2014 demonstrate the evangelical caucus' growing veto power.

With respect to this last initiative, the support of the Catholic Church, coupled with the growing use in Brazil of the notion of "gender ideology" (Miskolci and Campana, 2017; Junqueira, 2018), were fundamental to garnering support from various sectors of society against sex education in schools. The notion of "gender ideology" has worked as an empty signifier (Laclau and Mouffe, 2001; Kuhar and Paternotte, 2017) capable of creating chains of equivalences among different, and even contradictory, political agendas. The notion of gender ideology made it possible for Catholic and Evangelical leaders to articulate with right-wing groups, such as the Free Brazil Movement (MBL). The group was one of the main leaders in the movement for the impeachment of President Rousseff in 2015-16 (Vrydagh, 2020), defending a libertarian/pro-market ideology and engaging in the fight against "leftist indoctrination" in schools and universities. In this sense, to understand recent developments in anti-gender policies in Brazil, one must look at right-wing movements, their ideologies, repertoires of action and claims.

\section{Understanding the rise of the right: countermovements, blacklash politics, or new social movements?}

Over the last few decades, social movement academics have analyzed the specificities of conservative and right-wing movements (Klandermans and Meyer, 2005; Blee and Creasap, 2010; Rydgren, 2007; Castelli Gattinara and Pirro, 2019; Della Porta, 2020). One approach has identified such movements as "countermovements", that is, mobilisations that emerge in opposition to certain social agendas. Meyer and Staggenborg (1996) proposes a theoretical-analytical framework to understand countermovements, defining them as "a movement that makes contrary claims simultaneously to those of the original movement" (Meyer and Staggenborg, 1996: 1631). The central feature of countermovements is their connection to an opposing movement, influencing each other with respect to the repertoires of collective action, framing, and the use of the political opportunities. The emergence of 
counter-movements depends on the relative "success" of the opposing social movement in achieving public visibility and obtaining political-institutional gains (legislation, public policy, etc.) and the nature of the conflict in question. Claims that challenge deep-rooted values and traditions in society (such as abortion and LGBTQI+ rights) are more likely to generate countermovements.

Although these authors correctly emphasize the impact of social movements on their opponents, the notion of countermovement is limited. It ignores that opposition to a certain agenda can promote the emergence of social movements on its own, engendering demands that are not necessarily linked to the agendas of an adversary movement. Additionally, the analysis of countermovements has focused mainly on conservative movements, pointing out another limitation of the concept, which should be applied, in theory, to either progressive or conservative movements.

Thus, the present work follows the insights of academics who understand contemporary conservative and right-wing movements as social movements (Klandermans and Meyer, 2005; Blee and Creasap, 2010; Caiani et all, 2012; Vrydagh, 2020). There are, however, some challenges in this approach. The first refers to the defining features of "conservative" and "right-wing" movements, leading to a debate on the defining characteristics of the "left" and the "right". Although I cannot go deeper into this broad political-philosophical debate, I emphasize that "left" and "right" are historical, relational, and contextual categories whose defining features are constantly changing and depend on the specific context in which they are applied. Even so, I recognise, together with Bobbio (2001), that the commitment (or not) with the promotion of social equality is central to the definition of "left" and the "right". For Bobbio, the "left" would include those who understand inequalities as being socially constructed (and thus that they can be mitigated), while the "right" would include those who see inequalities as natural (and thus immutable). Nonetheless, social movements associated with the "right", far from constituting a homogeneous group, are "composed of different ideological tendencies, mobilizing around different issues, and using distinct action repertoires" (Caiani et all, 2012, p.3). Even recognizing the plurality of ideology and social actors and the difficulty in elaborating a definition capable of encompassing this diversity, Mudde (2000: 10-11) points out some common characteristics that would define the ideology of the extreme right: racism, xenophobia, nationalism, anti-pluralism, anti-communism, militarism. The extreme right also includes advocates for a strong populist political leadership and "Law and Order" policies. 
The second challenge refers to the difficulty in accessing right-wing movements. Since some operate underground due to links with terrorist groups, contacting right-wing activists can be a very arduous task. In addition, several of these groups use threats and violence to pursue their causes, placing researchers in a situation of vulnerability (Klandermans and Meyer, 2005; Blee and Creasap, 2010). However, the internet has become a valuable source of data for analyzing the ideologies defended by groups of right and extreme right and to monitor their actions in public spaces.

Most academics working with right-wing movements are affiliated with the Theory of Political Process. This text follows this trend, drawing inspiration from the insights of the Theory of Political Opportunities, as elaborated by Tarrow (2011). He defines the structure of political opportunities as "consistent - but not necessarily formal or permanent dimensions of the political struggle that encourage people to engage in contentious politics" (Tarrow, 2011, pp. 19-20). Among these dimensions, Tarrow highlights the presence of influential allies in the political system, the emergence of divisions between the members of the governing coalition and the decrease in the state's capacity to repress dissent.

According to Tarrow, these dimensions could facilitate and/or hinder collective action. In a context of a favourable structure of political opportunities, the action of "challengers" can expand the opportunities for other groups to organize themselves, characterizing "cycles of protests". Another relevant component of collective action is framing. It allows social movements to identify injustices, to assign responsibilities and to propose solutions to social problems. Along with framing, social networks are important for social movements. In times of state repression, they can remain "hidden", later emerging in a more favourable context to collective action. The conjunction of these external and internal factors defines the "power" of social movements.

\section{Methodology}

In the present study, I used a methodology inspired by the insights of Protest Event Analysis (PEA). PEA has been applied and improved since the 1970s for the analysis of the cycle of protests and mobilisations of different social movements. It has been largely used by academics engaged in the so-called "contentious politics" to analyse both case studies and long-term social mobilisation processes (McAdam, Tilly and Tarrow, 2001). PEA has been particularly promising in the systematic tracking of mobilisations and the characteristics associated with them (Beissinger, 2002). 
Hutter (2014) explores the different approaches, definitions, and methodologies of PEA. He points out that these methodologies were mainly focused on mobilisations driven by "progressive" social movements, emphasizing the "conflicting" dimension of the protest event. This posed important challenges to our research. First, different social and political actors which, despite being engaged in anti-gender politics, did not necessarily identify themselves as part of the same social movement. Second, as with other conservatives and right-wing movements, many individuals engaged in anti-gender politics are professional politicians, who use the institutional/conventional channels of representative democracy to advance their political agenda. This dimension was overshadowed by an emphasis on the "contentious" dimension of collective action.

Another important limitation of PEA concerns the selectivity of press coverage. As Lambelet (2009) points out, PEA would not consider mobilizations that have not been covered by the press. In addition, PEA would ignore movements and social actors for which visibility in the media is not part of their political strategy. Although I recognize these and other challenges, I agree with Beissinger (2002) when he affirms that the potential of PEA lies in its "adaptability to a wide variety of circumstances, depending on the researcher's purposes" (Beissinger 2002: 461)

To accommodate the particularities of our research object, I opted, as Opp (Opp, 2009: 38) for a broad definition of protest event as a "[...] action of individuals aimed at achieving their goal or goals by influencing decisions of a target." To identify the actors, dynamics of actions and changes of anti-gender politics in Brazil in recent years, I elaborated a SPSS database of articles published in the Folha de S. Paulo (FSP), Brazil's largest daily newspaper. To control potential biases from FSP's coverage, I also collected articles published on $O$ Globo, Brazilian second largest daily newspaper. However, I identified no major differences in the coverage of events related to anti-gender politics between these two publications. Therefore, following the insights of PEA, I decided to elaborate the database only with articles published on FSP to avoid possible repetitions.

The collection process was based on certain keywords related to important issues of recent events related to anti-gender politics in Brazil across both newspapers between 2011 and 2018. The reason for choosing these years lies in their relevance to anti-gender politics in Brazil. 2011 was the year of one of the main setbacks to LGBTQI+ rights: the suspension in the distribution of the "School without homophobia" (Escola sem homofobia), material elaborated by the Ministry of Education, as part of the "Brazil without homophobia" plan to capacitate high-school teachers in public institutions in dealing with issues of gender and 
sexuality. Jair Bolsonaro was a central figure in the lobbying against the material, together with neopentecostal congressmen. This can be seen as the beginning of the involvement of the extreme-right in the anti-gender politics in Brazil that would lead to Bolsonaro's election to the presidency in 2018.

The articles of Folha de S.Paulo are available through an online database ${ }^{2}$. Based on the chosen keywords ${ }^{3}$, the research resulted in 1,014 entries. Some entries were not directly related to any anti-gender politics event and were discarded. Folha de S. Paulo editorials were also discarded since the data might have been biased. There remained 439 articles. Many of the collected articles were discarded since they did not refer to a particular protest event. On the other hand, some articles included up to four different events and were recorded as different cases in our database. The analysis processed 178 anti-gender protest events between 2011 and 2018 .

\section{Analysing the anti-gender politics in Brazil (2011-2018)}

For each anti-gender protest event identified in FSP's articles between 2011 and 2018, I recorded the article's title, its date, and the date when the protest event happened. In some articles, there was no specific mention of the date of the protest event. In these few cases, I considered the article's publishing date as the date of the protest event. Regarding the timing of anti-gender protest events (henceforth AGPE), there is no clear pattern of evolution in time. However, it is possible to identify some peaks of mobilisation, observed in 2012, 2017, and 2018.

Graphic 1: Evolution of the anti-gender protest events (2011-2018)

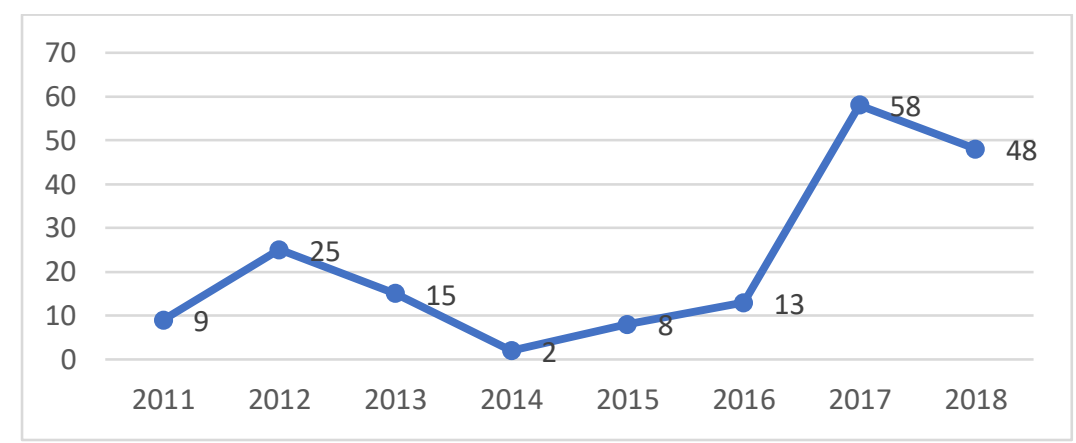

Source: Folha de S. Paulo

\footnotetext{
2 The database is available for Folha de S.Paulo subscribers at https://acervo.folha.com.br/index.do.

3 The keywords chosen were: "gender”, "sexual orientation”, "education national plan”, "gender ideology”, "gay kit”, "gay cure", "conversion therapy”, "antiabortion”, "pro-family movement”, “queer museum”, "march for Jesus”, "Schools without Party".
} 
In those years, there were episodes that mobilised social and political sectors against the promotion of gender equality and sexual diversity: a) the local election in the city of São Paulo in 2012; b) the Queer Museum exhibition and its repercussions in the field of arts in 2017; c) the public hearing on the decriminalization of abortion; and d) the election of Jair Bolsonaro, the last two episodes taking place in 2018. It is important to stress the relevance of the Queer Museum exhibition. It was opened in Porto Alegre in August 2017 and then closed on September $10^{\text {th }}, 2017$, after the wide mobilisation of conservative and religious sectors. The period between August and December 2017 concentrates 25.8\% of all AGPEs. These five months encompassed the period of the exhibition and the reactions in favour/against its cancellation. The high number of protest events in a relatively short period of time suggests the existence of a moral panic (Cohen, 2002; Goode and Ben-Yehuda, 2009), in which there is a disproportionate increase in media coverage on a specific topic or social group, seen by public opinion as a threat to society (Gomes da Costa, forthcoming).

In 2012 and 2018, elections were held (local and nationally, respectively) in which a common topic and person was at the centre of the political debate: the "School without homophobia" and Fernando Haddad, member of the Workers' Party (PT). In 2012, Haddad ran for mayor of the city of São Paulo and was widely attacked by his opponents for supposedly having proposed the "gay kit" when he was Minister of Education. The topic returned in 2018, now capitalized by Jair Bolsonaro, who was the one responsible for coining the pejorative term "gay kit" in 2011. If we look at AGPEs taking place during election years (2012, 2014, 2016 and 2018), they encompassed 50.9\% ( $\mathrm{N}=81)$ of cases, demonstrating the relevance of the electoral context for anti-gender politics in Brazil.

Regarding the place of occurrence of the AGPEs, 36\% ( $\mathrm{N}=64)$ occurred in Brasília, the federal capital. São Paulo and Rio de Janeiro, the first and the second largest cities appear in second and third place, with $27.5 \%(\mathrm{~N}=49)$ and $12.9 \%(\mathrm{~N}=22)$, respectively. The relevance of Brasília as the main locus of the AGPEs demonstrates the strongly institutional dimension of anti-gender politics in Brazil.

In the vast majority (89.9\%) of AGPEs reported between 2011 and 2018, it was not possible to identify the exact number of participants. As a way of circumventing the lack of information, "clues" contained in the analysed Folha de S. Paulo's articles were used to estimate the number of participants ${ }^{4}$. The values were assigned according to the following

\footnotetext{
4 The strategy of estimating the number of participants in protest events was applied in the research "Dynamics of Collective Protest in the U.S., 1960-1995" conducted by Stanford University. The database and coding scripts for the analysis variables are available at https://web.stanford.edu/group/collectiveaction/cgi-bin/drupal/ (Accessed on 29 April 2021).
} 
categories: 1 - Small, few (1-9 people); 2 - Group, committee (10 to 49 people); 3 - Large, gathering (50-99 people); 4 - Hundreds, mass, crowd (100-999 people); 5 - Thousands (1,0009,999 people); 6 - Tens of thousands (10,000 or more people). Based on the exact and estimated number of participants, AGPEs were classified into three categories: 1 -small (1 to 99 participants); 2 - moderate to large (100-9,999 participants) and 3 - mass (10,000 or more participants).

Table 1: Number of participants in AGPE

\begin{tabular}{lrr}
\hline & N & \% \\
\hline Small & 29 & $72,5 \%$ \\
Moderate to large & 5 & $12,5 \%$ \\
Mass & 6 & $15,0 \%$ \\
\hline Total & $\mathbf{4 0}$ & $\mathbf{1 0 0 , 0 \%}$ \\
\hline Source: Folha de S. Paulo & &
\end{tabular}

From the 40 AGPEs in which it was possible to obtain information (exact or estimated) on the number of participants, the majority $(72.5 \%$ ) were classified as small (from 1 to 99 participants). AGPEs with moderate and mass participation accounted for only $12.5 \%$ and $15 \%$ respectively. Of the mass events, two events stand out: 1) the "March for Jesus", organized annually by different evangelical denominations in São Paulo on the holiday of Corpus Christi and 2) the outdoor mass held by the Catholic Church during the visit of Pope Francis in 2013 in Rio de Janeiro. At the outdoor mass held at Copacabana beach, opposition to abortion (even in cases already legally allowed) played a prominent role, including the presence of the parents of an anencephalic child who handed the Pope an anti-abortion shirt. In 2012, the Brazilian Supreme Court had decriminalised termination of pregnancy in cases of anencephalic foetuses (Santos, 2012), under strong criticism from the Catholic Church and evangelical denominations.

In the case of the "March for Jesus", the anti-gender agenda was not isolated. The rejection of abortion and prostitution, criticism against the so-called "gay kit" and the spread of the "gender ideology" in schools were articulated with other issues relevant to conservative sectors, such as the fight against corruption (particularly the corruption scandals occurred during the Worker's Party administrations) and the use of marijuana and other recreational drugs, as well as for the support for civilians holding firearms and the supposed "ideological neutrality" in schools. This suggests the emergence of a 
conservative/right-wing frame in Brazil in which the economic and political crisis were intertwined with a moral crisis (Solano, 2020). This frame would be broadly applied by candidate Jair Bolsonaro in the 2018 election, particularly in the search for votes from the evangelical sector of the population.

It was possible to identify 273 mentions of key individuals who participated in AGPEs. The mentions were categorised to measure the weight of each political and religious segment in AGPEs. Politicians were categorised in three groups: a) members of the evangelical caucus; b) members of the Catholic caucus and c) other politicians. Similarly, religious leaders (Catholic and Evangelical) active in civil society were counted separately from those holding office in institutions of political representation.

Table 2: Number of mentions of AGPE key individuals

\begin{tabular}{lrr}
\hline & $\mathbf{N}$ & \% \\
\hline Members of the evangelical caucus & 93 & $34,1 \%$ \\
Other politicians & 49 & $17,9 \%$ \\
"New-right" activists & 38 & $13,9 \%$ \\
Evangelical leaderships & 34 & $12,5 \%$ \\
Catholic leaderships & 13 & $4,8 \%$ \\
Members of the judiciary & 13 & $4,8 \%$ \\
Pro-life activists & 13 & $4,8 \%$ \\
Members of the Catholic caucus & 8 & $2,9 \%$ \\
Others & 12 & $4,4 \%$ \\
\hline Total & $\mathbf{2 7 3}$ & $\mathbf{1 0 0 , 0} \%$ \\
\hline
\end{tabular}

Source: Folha de S. Paulo

The evangelical caucus in Congress is the main actor, with $34.1 \%$ of all mentions. Together with other evangelical leaders, they make up almost half (46.6\%) of all mentions. Politicians and leaders with religious ties represented the highest number of mentions $(54.3 \%)$, confirming the relevance of Christian religions on anti-gender policies in Brazil. To identify possible changes in the prominence of different social groups between 2011 and 2018, I crossed the mentions of key individuals with the year of AGPEs. 
Graphic 2: Mentions of key individuals by AGPE's year

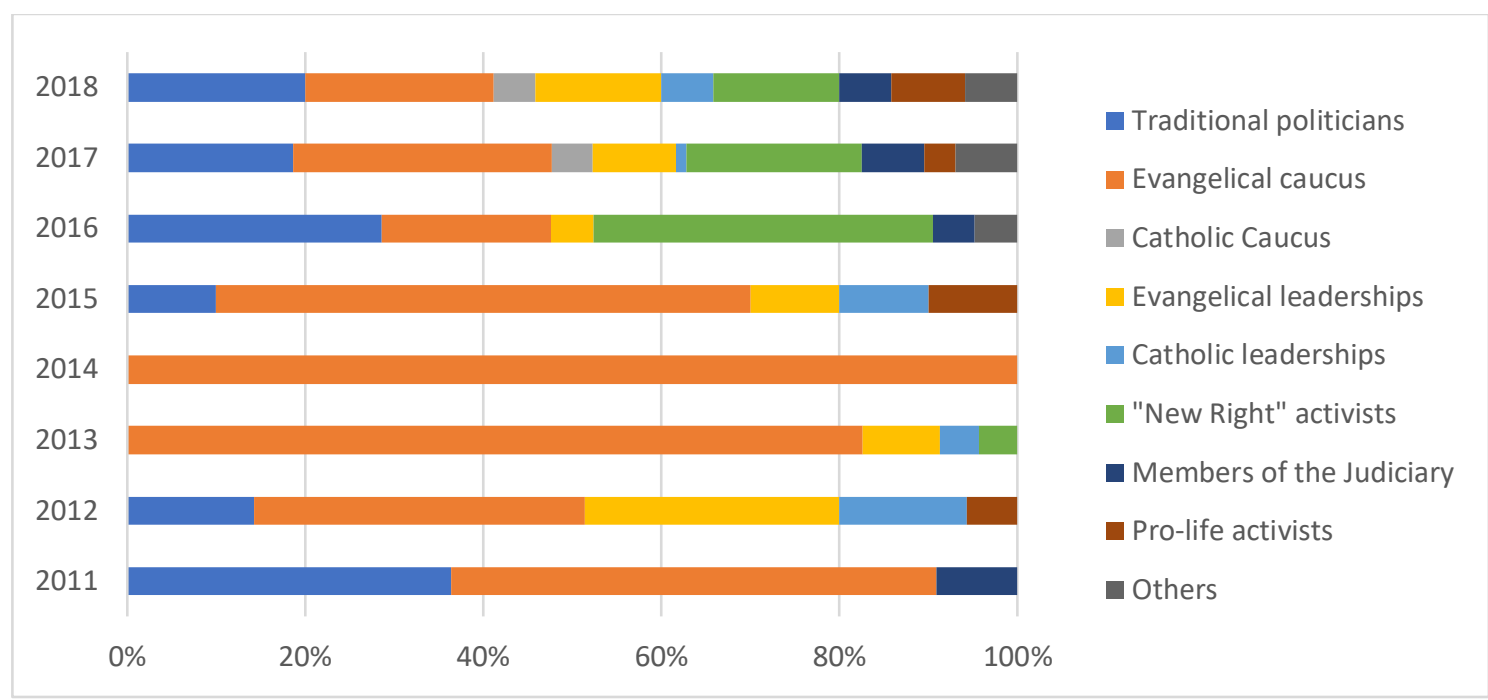

Source: Folha de S. Paulo

The graph points to the pluralization of social actors involved in AGPEs. Until 2015, members of the evangelical caucus and other evangelical leaders dominated AGPEs. From 2016 on, we can see the involvement of "new right" activists with 13.9\% of mentions. The "new right activists" are those who emerged mainly amid the mobilisations demanding Dilma Rouseff's impeachment between 2014 and 2016 (Solano, 2018; Casimiro, 2018; Velasco Cruz et. Al, 2015; Vrydagh, 2020). The label "new right" does not necessarily refer to new ideologies and demands, but to the new ways of organising and occupying the public sphere, particularly through an innovative use of the internet (Cardoso, 2020). The Free Brazil Movement (MBL) features prominently among the "new right" groups. Founded in late 2014, the MBL was one of the main groups engaged in mobilisations that took hundreds of thousands to the streets to demand the removal of President Rousseff (Vrydagh, 2020). In 2017, the group played a prominent role in the media by mobilising public opinion against the Queer Museum exhibition launched in Porto Alegre. The exhibition was accused of profaning Christian religious symbols and promoting paedophilia with the use of public funds ${ }^{5}$, resulting in its cancellation. The successful mobilisation against the Queer Museum exhibition led the MBL to "embrace" the moral agenda, assuming a prominent position in AGPEs in Brazil.

\footnotetext{
5 The Queer Museum exhibition received public funds via the Rouanet Law (Law No. 8,313 / 1991). The law provides for the possibility of companies and private citizens to use part of the due income tax to fund cultural activities. The law has been the target of several criticisms from conservative sectors, which denounce the alleged use of public resources in cultural activities that would confront the Christian moral values of most of the Brazilian population.
} 
I also identify organisations taking part in AGPEs. Only organisations explicitly mentioned as organizers and/or participants of an AGPEs were counted in this variable. Like the variable "Key individuals", the unit of analysis here is the mention, since the same AGPE may have counted on the participation of more than one organization.

Table 3: Mentions of organisations participating in AGPE

\begin{tabular}{lrr}
\hline & $\mathbf{N}$ & $\mathbf{\%}$ \\
\hline "New right" organisations & 27 & $31,8 \%$ \\
Legislative branch (congress caucuses) & 19 & $22,4 \%$ \\
Catholic Church & 12 & $14,1 \%$ \\
Evangelical churches & 10 & $11,8 \%$ \\
Executive branch & 7 & $8,2 \%$ \\
Judicial branch & 2 & $2,4 \%$ \\
Political parties & 1 & $1,2 \%$ \\
Others & 7 & $8,2 \%$ \\
\hline Total & $\mathbf{8 5}$ & $\mathbf{1 0 0 , 0} \%$ \\
\hline
\end{tabular}

Source: Folha de S. Paulo

The table above confirms the importance of organizations linked to the "new right" in AGPEs in Brazil. The MBL's involvement in the controversy surrounding the Queer Museum exhibition accounts for a good part of this percentage of mentions (31.8\%). The closing of the exhibition in Porto Alegre in September 2017 triggered a sequence of other mobilisations against other artistic activities that addressed the issue of sexual and gender diversity. An example was the controversy surrounding the performance "La Bête" performed by choreographer Walter Schwartz at the Museum of Modern Art (MAM) in São Paulo. The performance was accused of promoting paedophilia after the disclosure of a photo on the internet in which a child, apparently accompanied by his/her mother, touches the choreographer's naked body. The MBL promoted online and offline mobilisations, resulting in a complaint to the Public Prosecutor's Office against the artist and the museum (Gomes da Costa, forthcoming).

After the "new right" groups, congress caucuses appeared as the second largest $(22.4 \%)$ organisation taking part in AGPEs. The Catholic Church and the different evangelical denominations make up $14.1 \%$ and $11.8 \%$ respectively of the organisations engaged in AGPE. Together, the Christian churches accounted for $25.9 \%$ of the mentions to organisations promoting and/or participating in AGPE, corroborating once again the relevant role of Christian religions in the anti-gender politics in Brazil. 
Table 4: Targets mentioned in AGPE

\begin{tabular}{lrr}
\hline & N & \% \\
\hline Executive branch & 26 & $23,0 \%$ \\
Cultural organisation/entity & 25 & $22,1 \%$ \\
Politicians & 24 & $21,2 \%$ \\
Professional associations & 14 & $12,4 \%$ \\
Professors/teachers/intellectuals/artists & 9 & $8,0 \%$ \\
Judicial branch & 5 & $4,4 \%$ \\
Others & 10 & $8,8 \%$ \\
\hline Total & $\mathbf{1 1 3}$ & $\mathbf{1 0 0 , 0} \%$ \\
\hline
\end{tabular}

Source: Folha de S. Paulo

Another variable analysed was the target of AGPEs. Politicians and governmental and judicial institutions prefigured the main target of AGPE, with almost half $(48.1 \%)$ of the mentions identified in analysed articles. The state, its institutions, and representatives are the prime targets for protest events for different social movements. This is due to the importance of state institutions as the main regulatory entity of social relations in contemporary societies (Tarrow, 2011; Melucci, 1996). The particularity of AGPEs lie, however, in the importance of the cultural sector as a privileged target. The cultural sector has only gained importance in AGPEs more recently, after 2015, as can be seen in the following graph.

Graph 4: Targets mentioned by AGPE's year

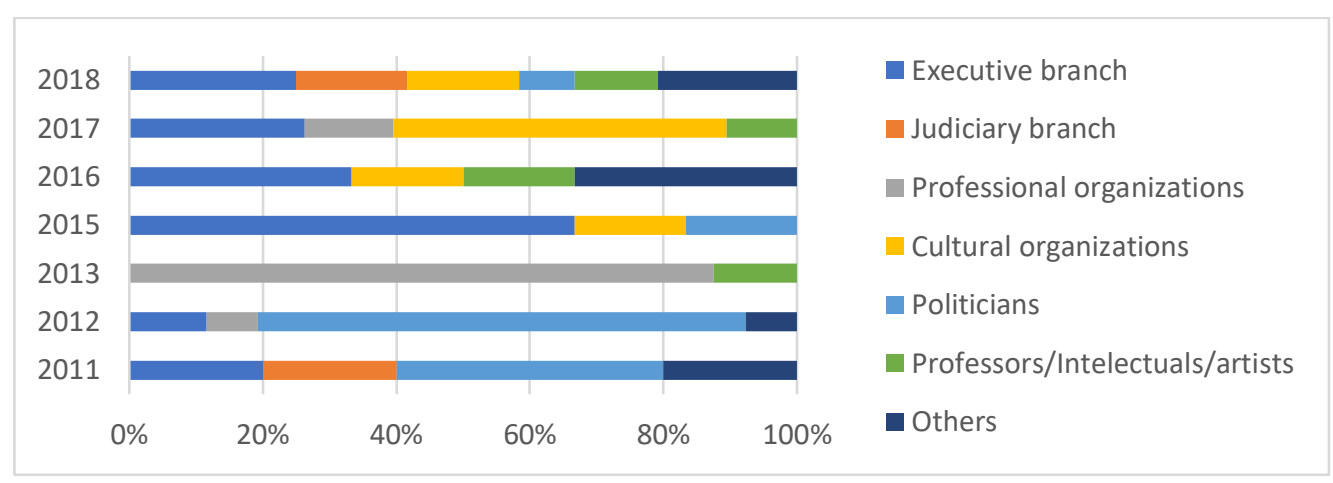

Source: Folha de S. Paulo

Considering only the targets between 2016 and $2018(\mathrm{~N}=68)$, almost half of them (47.1\%) were cultural entities (museums and cultural centres) as well as artists, intellectuals, and teachers. The greater relevance of the cultural and intellectual sector as a target for antigender protest events is possibly linked to the growing role of the "new right" groups, 
especially the MBL. The group was prone to import the model of "culture wars" that have been widely used by US-based conservative and alt-right groups (Hartman, 2019). Together with other "new right" groups, the MBL has stressed the existence of a supposed hegemony of the left in the cultural field. Criticisms of the so-called "cultural Marxism" proliferate among these groups (Solano, 2018; Lacerda, 2019; Goldstein, 2019) and the issues of gender and sexual diversity are seen by conservative sectors as the main "weapons" of the left in a supposed "war" being waged against Christian values. These arguments are present in several anti-gender mobilisations in Europe (Kuhar and Paternotte, 2017; Dietze and Roth, 2020) and Latin America (Prado and Corrêa, 2018).

This work also sought to identify the claims made by individuals and groups engaged in anti-gender politics. In most of the AGPEs, one or more claims were identified, making it necessary to use the mention of each claim as a unit of analysis. The five most recurrent claims of AGPEs were: 1) opposition to the "gay kit" (12.6\%); 2) opposition to the teaching of "gender ideology" in schools (11.9\%); 3) support for ideological neutrality in schools $(9.9 \%) ; 4)$ opposition to abortion $(9.5 \%)$, and 5) opposition to the Resolution 01/1999 which prohibited the treatment of homosexuality as a disease (also known as the "gay cure") (5.9\%). These claims show the importance of education as an area of dispute in anti-gender politics, similarly to what Schmincke (2020) identifies as "the holy trinity" of sexual politics from the right: gender, sexual diversity, and sex education. This becomes more explicit when we aggregate similar claims into one category. The opposition to the "gender ideology" and the teaching of gender and sexual orientation represent almost a third (31.2\%) of all the identified claims.

Table 5: Claims mentioned on AGPE

\begin{tabular}{lrr}
\hline & N & \% \\
\hline Gender ideology/sexual orientation in & & \\
education/schools & 79 & $31,2 \%$ \\
"New right" / "Cultural Marxism" & 38 & $15,0 \%$ \\
Abortion & 30 & $11,9 \%$ \\
Censorship in arts and literature & 24 & $9,5 \%$ \\
Children sexuality & 16 & $6,3 \%$ \\
Gay cure (Resolution CFP 01/1999) & 15 & $5,9 \%$ \\
Trans rights & 5 & $2,0 \%$ \\
Same-sex unions & 4 & $1,6 \%$ \\
Others & 42 & $16,6 \%$ \\
\hline Total & $\mathbf{2 5 3}$ & $\mathbf{1 0 0 , 0} \%$ \\
\hline \multicolumn{3}{c}{ Source: Folha de S. Paulo }
\end{tabular}


Recent studies (Penna, 2018; Mattos, 2018; Vencatto et al., 2018) stress education as the new arena of dispute for social groups opposing gender equity and sexual diversity in Brazil. Several anti-gender groups mobilised between 2014 and 2016, successfully lobbying for the exclusion of all mentions to gender and sexual orientation in the education plans national and locally.

Another example of disputes around education is the self-identified movement "Schools without Party", created in 2004 by the lawyer Miguel Nagib. In its initial proposal, the movement preached schools' "ideological neutrality", in response to a supposed "leftist" hegemony in the Brazilian field of education. The proposal provided for the right of parents and guardians to question the content delivered in the classroom. It also included the punishment of teachers accused of violating students' beliefs and freedom of conscience ${ }^{6}$. The movement gained visibility when, in 2015, a law inspired by the movement's recommendations was approved in the state of Alagoas. At the federal level, congressman Izalci Lucas presented a bill incorporating the "Schools without Party" movement's proposal almost in its entirety. The first version of the project made no mention of "gender ideology". The term was later included in 2018 by congressman Flavinho, as a result of the strategy of the "Schools without Party" movement to garner support from religious sectors. From then and on, the "Schools without Party" bill became one of the main banners of religious and extreme right groups, gaining intense visibility in the press.

Finally, this article sought to point out the repertoire of action applied by individuals/organisations engaged in the anti-gender protest events. As in the variables "key individuals", "organisation", "target" and "claims", the paper identified at least one repertoire of action in several of the AGPEs. Altogether, I identified 41 different repertoires of action. They range from more conventional actions (such as lobbying, presentation of bills, participation in public hearings, etc.), through to more disruptive actions (holding demonstrations and protests, promoting boycotts) and even more violent actions, such as threats. The five most frequent repertoires of action were: 1) interviews $(10.5 \%)$; 2$)$ campaigns/protests on social media $(7.6 \%) ; 3)$ the presentation of bills $(7.1 \%)$; 3 ) lobbying $(6.7 \%) ; 4)$ demonstration and protests $(5.7 \%)$, and 5$)$ the approval of legislation $(5.2 \%)$. Excluding demonstrations and protests, the four most performed repertoires of action are

\footnotetext{
${ }^{6}$ Recently, the Spanish extreme-right party Vox tried to push forward a similar legislation, called by the media "PIN parental", allowing parents to veto complementary activities allegedly "controversial" issues to their children during classroom time (El País, 2020). A same movement is happening in the US. Republican-led legislatures have passed bills banning or limiting the teaching of Critical Race Theory in schools (Gabriel and Goldenstein, 2021).
} 
conventional, within the institutional channels of representation. This reinforces the hypothesis that anti-gender politics in Brazil are institutional in nature.

If we aggregate similar repertories into broader categories, the institutional dimension becomes even more explicit. The first category, which accounts for more than a quarter of the repertoires of actions (28.6\%), is related to political-parliamentary life (lobby, presentation, debate and approval of legislation, commissions and public hearings, parliamentary speeches, etc.). The second category of repertoires of action most identified in AGPEs (16.2\%) was the holding of virtual demonstrations and protests. Several authors (Pleyers, 2018; Castells, 2018; Alcântara, 2016; Vrydagh, 2020) stress the relevance of the internet as a space for interaction and articulation of activism networks, information exchange, and political mobilisation.

Table 6: Repertoires of action performed in AGPE

\begin{tabular}{lrr}
\hline & $\mathbf{N}$ & $\%$ \\
\hline Lobbying/ activities in representative & & \\
institutions & 60 & $28,6 \%$ \\
Virtual protest/ mobilisation (online) & 34 & $16,2 \%$ \\
Interviews/Participations in radio/TV & & \\
programs & 29 & $13,8 \%$ \\
Protest/mobilisation in the public sphere & & \\
(offline) & 22 & $10,5 \%$ \\
Electoral and partisan activities & 11 & $5,2 \%$ \\
Lawsuits & 10 & $4,8 \%$ \\
Threats & 8 & $3,8 \%$ \\
Others & 36 & $17,1 \%$ \\
\hline Total & $\mathbf{2 1 0}$ & $\mathbf{1 0 0 , 0} \%$ \\
\hline
\end{tabular}

Source: Folha de S. Paulo

If we compare the repertoires of action with the year of protest events, we can identify certain changes. The first change is the pluralization of the repertoires of action, especially in years in which we observe "peaks of mobilisation". When it comes to parliamentary, electoral, and partisan activities, they varied over the years, but they always occupied a prominent position in anti-gender politics in Brazil. 
Graph 5: AGPE repertoires of action by year

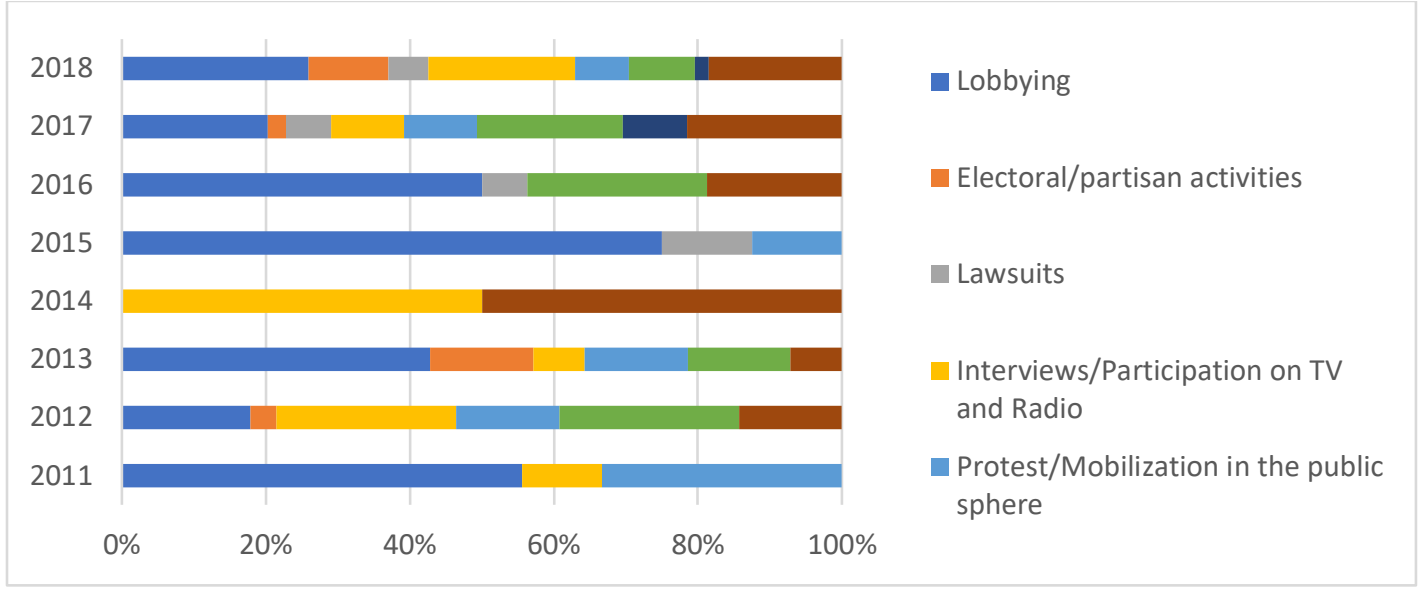

Source: Folha de S. Paulo

The use of the internet in AGPEs dates back to 2012. However, its peak occurred in 2017, when we witnessed the mobilisations against the Queer Museum exhibition. The MBL was forged in the virtual environment around 2014 and it has made extensive use of virtual tools to mobilize its followers since (Vrydagh, 2020).

Two other "innovations" in relation to repertoires of action are the use of "lawsuits" and "threats" as tools of political action. These became more present in AGPEs after 2015 amid two processes that strongly impacted recent Brazilian politics: the growing politicization of the Judiciary and the resurgence of the "new right" groups in the public space. Both processes have been fed back, mainly after the start of the anti-corruption “Operation Car Wash" in 2014 (Avritzer, 2019; Cardoso, 2020). The media's biased coverage of the operation disproportionately emphasized the role of the leaderships of the thenruling-Workers' Party in the corruption scandals, spreading an Anti-Workers' Party sentiment (anti-petismo) amongst the general public opinion, which portrayed the party (and the Left more broadly) as intrinsically corrupt and responsible for all the existing evils in Brazilian politics (Solano, 2019).

Anti-petismo was reinforced by the existence of promiscuous relationships between prosecutors and judges involved in Operation Car Wash ${ }^{7}$. They infringed the principles of impartiality, independence, and equidistance between defence and prosecution. Anti-

\footnotetext{
7 The website The Intercept Brasil (Greenwald et. al, 2019) disclosed messages exchanged through the application Telegram between judge Sérgio Moro, responsible for the Operation "Car Wash", and the public prosecutors and the Federal Police. In them, Moro gave instructions to the prosecutors on how lead the accusation against Lula da Silva, even suggesting the extensive use of media to build a case against the former president in the public opinion.
} 
petismo has also resurfaced a latent anti-communist sentiment that permeated the discourses of right-wing groups (mainly among the military) in Brazil in the 1950s, 1960s, and 1970s (Cowan, 2016). Recent formulations such as the so-called "cultural Marxism" has updated the anti-communist sentiment (Cardoso, 2020; Lacerda, 2019; Motta, 2019). The "Bolivarian threat" represented by the governments of Hugo Chávez and Nicolas Maduro in Venezuela has been extensively used by the renewed anti-communist rhetoric (Lacerda, 2019; Motta, 2019). The growing prominence of the anti-communist extreme right and the strength of anti-petismo in society was central to Jair Bolsonaro in 2018 as he garnered support for his candidacy.

\section{Final remarks}

This article aimed to analyse anti-gender politics in Brazil and its possible impacts on the recent authoritarian turn represented by the election of Jair Bolsonaro in 2018. Inspired by the literature on social movements, the article identified individual and collective actors engaged in anti-gender politics, the targets of their mobilisations, their claims, and repertoires of action. The data has shown that religious leaders, particularly neoPentecostals, are still the main protagonists of anti-gender politics in Brazil. Between 2011 and 2018, neo-Pentecostal leaderships and denominations stood out as the most engaged in AGPEs. However, the data suggests that since 2016, the "new right" has increasingly taken part in AGPEs. Groups such as the Free Brazil Movement (MBL) stood out in organising AGPEs, articulating their pro-market and anti-communist/ "leftist" agendas with the opposition to sexual and reproductive rights, echoing a recent elective affinity between neoliberalism and new conservatism (Brown, 2019; Cooper, 2017). The engagement of the "new right" in AGPEs leads to significant changes not only in the targets of the mobilisations and repertoires of action, but also in their claims.

Until 2015, the main target of anti-gender mobilisations were state actors (with emphasis on the executive and judiciary branches) and professional politicians, demonstrating a relevant feature of anti-gender politics in Brazil: their political-institutional character. This is demonstrated by the centrality of Brasília as the locus of AGPEs, the small number of participants, the relevance of the electoral years for the mobilizations and the wide use of lobbying as a repertoire of action. From 2016, with the increasing engagement of the "new right" in AGPEs, the targets of mobilizations became more plural. Cultural organizations, artists, intellectuals, and teachers, as well as education in general became targets of AGPEs. In this sense, the "new right" contributed to importing "cultural wars" 
into Brazil, widely used by conservative and far-right groups in the US (Hartman, 2019). Although the mobilisations continue to gather a relatively low number of participants, they became more disruptive, with the use of new repertoires of action, particularly the intensive use of the internet as a tool for online and offline mobilisation and an increasing number of threats as a strategy for political action.

The growing participation of the "new right" in AGPEs contributed to the inclusion of opposition to sexual and reproductive rights into a conservative/right-wing framework. This framework has characterized Brazil's economic and political instability, the visibility of the political class' corruption scandals by the media, and the demands of LGBTQI+ and feminists' activists as symptoms of a major moral crisis (Solano, 2020). The notion of gender ideology has been operating as an "empty signifier" (Laclau and Mouffe, 2001; Kuhar and Paternotte, 2017) capable of articulating anti-gender agendas, such as the rejection of abortion, same-sex unions, prostitution, sexual education, and queer cultural expressions with conservative/right-wing claims such as the fight against corruption, the legalisation of recreational drugs, the ideological/leftist indoctrination of schools and universities, as well as the promotion of "Law and Order" policies. "Gender ideology" allowed the "new right" to articulate the moral agenda with the anti-petismo disseminated in the collective imaginary, mobilising not only conservative and right-wing groups and individuals, but also important segments of the centrist constituency.

Bolsonaro was central in the process of articulating conservative and right-wing groups around the anti-gender agenda. Since his criticism against the so-called "gay kit" in 2011, the former congressman has gained prominence in the press with his radical rightwing position, becoming a sort of spokesman for anti-petismo. Until mid-2013, the former captain was constantly mocked by the media as a bizarre ultraconservative backbencher. However, after the 2013 Journeys of June, a context of favourable political opportunities (Tarrow, 2001) arose for conservative and right-wing groups, many of whom were excluded from the broad coalition of support for the Workers' Party administration. The party's historic commitment to social movements and democracy created a context of freedom for conservative and right-wing groups to organize and occupy the public sphere without resistance or repression. Dilma Rousseff's tight re-election in 2014 and the refusal of her opponent, Aécio Neves, to accept the results, operated as an incentive for more radicalised groups to take the lead in opposition against the Workers' Party. It was in this context that the impeachment movement emerged, taking hundreds of thousands to the streets. The MBL was one of its main organisers (Vrydagh, 2020). 
The movement's success in deposing President Rousseff gave right-wing groups important political strength. Amid the impeachment mobilisations, Bolsonaro intensified contacts with conservative groups, especially with members of the evangelical caucus. Even though he identified himself as Catholic, the congressman was baptized in 2016 in the waters of the Jordan River in Israel by pastor Everaldo, a prominent neo-Pentecostal leader who ran for president in 2014 (Almeida, 2017). The baptism symbolically sealed the alliance between neo-Pentecostal leaders and Bolsonaro. From then on, Bolsonaro travelled through the country to gather new allies, always being welcomed by fervent supporters. Even in early 2018, many of Bolsonaro's supporters still did not believe in the viability of his candidacy. However, the confirmation of the arrest of former President Lula da Silva by the Supreme Court and the poor performance of the centre and right-wing candidacies turned Bolsonaro into a strong competitor. The broad mobilisations against his candidacy led by the \#NotHim movement and the controversial knife attack suffered during the campaign consolidated Bolsonaro as leader of a broad conservative front, which was articulated by pro-market centre-right groups as well as the radical right, who defended military intervention.

Bolsonaro's rise to power in 2019 resulted in the empowerment of these right-wing extremist groups and triggered a process of deterioration of democratic institutions, an unprecedented political process in Brazil's recent history. The increasing presence of members of the armed forces in different areas of public administration has turned Bolsonaro's administration into a "de facto" military government. The advance against institutions of social and institutional control (national congress, councils, universities, media, judiciary) has intensified. The "anti-gender approach" has become a government policy through the increasing presence of politicians from the religious caucuses (with an emphasis on the evangelical caucus). The anti-gender agenda, coupled with the proagrobusiness, pro-market, and pro-gun agendas, have converted the Brazilian State into a threat to the existence and safety of vulnerable social groups, such as indigenous people, black people, women and LGBTQI+ people, in addition to jeopardizing the environment. In this sense, the Brazilian case seems to be an example of the economic, political and social consequences of the rise of the extreme-right to power and the threat it can pose both locally and globally.

The COVID-19 pandemic and the consequent deterioration of the country's economy and public health were not able to stop the actions of the more radicalised sectors of Bolsonaro's administration. Furthermore, the anti-gender rhetoric remains fundamental for Bolsonaro to mobilise his most loyal constituencies. At the height of the first wave of the 
pandemic, in July 2020, Bolsonaro declared that the use of the mask as a strategy to fight the spread of the virus was a "faggot thing" (Moreira, 2020). The pandemic led to the removal of several centre-right groups from the government. The MBL, which supported Bolsonaro in 2018, has criticised Bolsonaro's denialism of the sanitary crisis. Despite the current crisis, the president is managing to maintain the support of around a quarter of the Brazilian electorate, particularly among neo-Pentecostal constituencies. This suggests that the antigender agenda is still far from becoming secondary in Brazilian contemporary politics.

\section{Bibliography}

Almeida, R. D. (2017) 'A onda quebrada-evangélicos e conservadorismo'. Cadernos Pagu, (50).

Avritzer, L. (2019) O pêndulo da democracia. Todavia.

Beissinger, M. (2002) Nationalist Mobilization and the Collapse of the Soviet State. Cambridge: Cambridge University Press.

Blee, K. M. and Creasap, K. A. (2010) 'Conservative and right-wing movements', Annual review of sociology, 36, pp. 269-286.

Bobbio, N. (2001) Direita e Esquerda razões e significados de uma distinção política. Unesp.

Brown, W. (2019) In the ruins of neoliberalism: the rise of antidemocratic politics in the West. Columbia University Press.

Caiani, M., Della Porta, D. And Wagemann, C. (2012) Mobilizing on the extreme right: Germany, Italy, and the United States. Oxford University Press.

Cardoso, A. (2020). À beira do abismo: Uma sociologia política do bolsonarismo. Amazon.

Casimiro, F. H. C. (2016). A nova direita no Brasil: aparelhos de ação político-ideológica e a atualização das estratégias de dominação burguesa (1980-2014). Expressão Popular.

Castelli Gattinara, P. and Pirro, A. L. (2019) 'The far right as social movement', European Societies, 21(4), pp. 447-462.

Castells, M. (2018) Ruptura: a crise da democracia liberal. Editora Schwarcz-Companhia das Letras.

Cohen, S.(2002) Folk devils and moral panics: the creation of the mods and rockers. Oxford: Blackwell.

Cooper, M. (2017) Family values: Between neoliberalism and the new social conservatism. MIT Press.

Corrêa, S., Petchesky, R., and Parker, R. (2008) Sexuality, health and human rights. Routledge.

Corrêa, S. and Parker, R. (Eds.) (2011) Sexualidade e politica na America Latina. Rio de Janeiro, Sexuality Policy Watch..

Corrêa, S. (2018) 'A "política do gênero": um comentário genealógico', Cadernos Pagu, (53).

Cowan, B. A. (2016). Securing sex: morality and repression in the making of cold war Brazil. UNC Press Books.

Della Porta, D. (2020) 'Conceptualising backlash movements: A (patch-worked) perspective from social movement studies', The British Journal of Politics and International Relations, 22(4), pp. 585-597. 
Dietze, G. and Roth, J. (Eds.) (2020) Right-Wing Populism and Gender: European Perspectives and Beyond. Transcript Verlag.

Eaton, K. (2014) 'New strategies of the Latin American Right: beyond parties and elections', in. Luna, J. P., \& Kaltwasser, C. R. (Eds.) (2014) The resilience of the Latin American right. JHU Press, pp. 75-93.

El País (2020) 'Qué es lo que Vox llama 'pin parental?' January, 21st. Available at: https:/elpais.com/sociedad/2020/01/17/actualidad/1579258136 624639.html/ (Accessed: 29 April 2021).

Fassin, É. (2017) Populisme: le grand ressentiment. Éditions Textuel.

Foa, R. S., and Mounk, Y. (2017) 'The signs of deconsolidation', Journal of democracy, 28(1), pp. 5-15.

Fukuyama, F. (2018) Identity: Contemporary identity politics and the struggle for recognition. Profile books.

Gabriel, T. and Goldenstein, D. (2021) 'Disputing Racism's Reach, Republicans Rattle American Schools'. The New York Times, June 1st. Available in https://www.nytimes.com/2021/06/01/us/politics/critical-racetheory.html (Accessed: 17 September 2021)

Goode, E. and Ben-Yehuda, N. (2009) Moral Panics: The Social Construction Of Deviance, Pondicherry.

Goldstein, A. (2019) 'A ascensão da direita radical brasileira no contexto internacional, in Bohoslavsky, E. L., Motta, R. P. S. and Boisard, S. (Eds.) Pensar as direitas na América Latina. Alameda.

Gomes da Costa Santos, G. (2011). Cidadania e direitos sexuais: um estudo comparativo do reconhecimento legal das uniões entre pessoas do mesmo sexo no Brasil e na África do Sul. PhD Dissertation in Political Science, State University of Campinas (Unicamp)

(2016). "Movimento LGBT e partidos políticos no Brasil". Contemporânea-Revista de Sociologia da UFSCar, 6(1), 179-179.

Gomes da Costa Santos, G., Melo, B. L. R. (2019), “The opposition to LGBT rights in the Brazilian National Congress (1986-2016). Actors, dynamics of action and recent developments", Sociologies in Dialogue, vol. 4, no 1, p. 80-108.

. (Forthcoming), "Politique anti-genre et panique morale au Brésil: L'extrême droite et le tournant autoritaire dans la politique contemporaine", Émulations - Revue de Sciences Sociales.

Greenwald, G., Reed, B. and Demori, L. 'Como e por que o intercept está publicando chats privados sobre a Lava Jato e Sergio Moro' The Intercept - Brasil, June 9th Available at https://theintercept.com/2019/06/09/editorial-chats-telegram-lava-jato-moro/ (Accessed: 29 April 2021)

Hartman, A. (2019). A war for the soul of America: A history of the culture wars. University of Chicago Press.

Hutter, S. (2014) ‘Protest event analysis and its offspring', In. Donatella della Porta (ed.). Methodological practices in social movement research. Oxford University Press.

Junqueira, R. D. (2018) 'A invenção da" ideologia de gênero": a emergência de um cenário político-discursivo e a elaboração de uma retórica reacionária antigênero', Revista Psicologia Política, 18(43), pp. 449-502.

Klandermans, B. and Mayer, N. (2005). Extreme right activists in Europe: Through the magnifying glass. Routledge.

Kuhar, R. and Paternotte, D. (eds.) (2017) Anti-Gender Campaigns in Europe: Mobilizing against Equality. London: Rowman andLittlefield International.

Lacerda, M. B. (2019). O novo conservadorismo brasileiro: de Reagan a Bolsonaro. Editora Zouk.

Laclau, E. and Mouffe, C. (2001) Hegemony and Socialist Strategy: Towards a Radical Democratic Politics. Verso; 2nd edition, 2001.

Lambelet, A. (2009) 'Analyse événementielle', in Olivier Fillieule(ed) Dictionnaire des mouvements sociaux. Paris: Presses de Sciences Po.

Levitsky, S.,and Ziblatt, D. (2018) How democracies die. Broadway Books. 
Luna, J. P., \& Kaltwasser, C. R. (Eds.) (2014) The resilience of the Latin American right. JHU Press.

Mainwaring, S., Meneguello, R. and Power, T. J. (2000) Partidos conservadores no Brasil contemporâneo: quais são, o que defendem, quais são suas bases. Paz e Terra.

Matos, A. P. (2018) ‘Discursos ultraconservadores e o truque da "ideologia de gênero": gênero e sexualidades em disputa na educação', Revista Psicologia Política, 18(43), pp. 573-586.

McAdam, D., Tarrow, S. and Tilly, C. (2001) Dynamics of contention. New York and London: Cambridge University Press.

Melucci, A. (1996). Challenging codes: Collective action in the information age. Cambridge University Press.

Meyer, D. S. and Staggenborg, S. (1996). 'Movements, countermovements, and the structure of political opportunity', American journal of sociology, 101(6), pp. 1628-1660.

Miskolci, R. and Campana, M. (2017) '"Ideologia de gênero": notas para a genealogia de um pânico moral contemporâneo'. Sociedade e Estado, 32(3), pp. 725-748.

Moreira, J. A. (2020) '"Máscara é coisa de viado", dizia Bolsonaro a funcionários'. Diário de Notícias, July 9th. Available at https://www.dn.pt/mundo/mascara-e-coisa-de-viado-dizia-bolsonaro-a-funcionarios12405019.html (Accessed: 29 April 2021)

Motta, R. P. S. (2019) 'Anticomunismo, antipetismo e o giro direitista no Brasil', in Bohoslavsky, E. L., Motta, R. P. S. and Boisard, S. (Eds.) Pensar as direitas na América Latina. Alameda.

Mudde, Cas. (2020) O regresso da ultradireita: da direita radical à direita extremistas. Lisboa, Editorial Presença.

Norris, P., and Inglehart, R. (2019) Cultural backlash: Trump, Brexit, and authoritarian populism. Cambridge University Press.

Opp, K.-D. (2009) Theories of Political Protest and Social Movements. A Multidisciplinary Introduction, Critique, and Synthesis. London: Routledge.

Penna, F. A. (2018) 'A tentativa reacionária de censura nos currículos escolares: compreendendo a subversão mútua entre as lógicas de socialização e subjetivação', Revista Psicologia Política, 18(43), pp. 557-572.

Pinheiro-Machado, R. (2019) Amanhã vai ser maior: o que aconteceu com o Brasil e possíveis rotas de fuga para a crise atual. Planeta Estratégia.

Pleyers, G. (2018) Movimientos sociales en el siglo XXI. Perspectivas y herramientas analíticas. Buenos Aires, CLACSO.

Prado, M. A. M. And Corrêa, S. (2018) ‘Retratos transnacionais e nacionais das cruzadas antigênero', Revista Psicologia Política, 18(43), pp. 444-448.

Przeworski, A. (2019) Crises of democracy. Cambridge University Press.

Quadros, M. P. D. R. and Madeira, R. M. (2018) ‘Fim da direita envergonhada? Atuação da bancada evangélica e da bancada da bala e os caminhos da representação do conservadorismo no Brasil', Opinião Pública, 24(3), pp. 486-522.

Rydgren, J. (2007) 'The sociology of the radical right', Annual Review of Sociology, 33, pp. 241-262.

Rodrigues, L. M. (1987) Quem é quem na Constituinte: uma análise sócio-política dos partidos e deputados. OESP.

Santos, D. (2012) ‘Supremo decide por 8 a 2 que aborto de feto sem cérebro não é crime', Portal G1, April 14th. Available at http:/g1.globo.com/brasil/noticia/2012/04/supremo-decide-por-8-2-que-aborto-de-feto-semcerebro-nao-e-crime.html. (Accessed: 29 April 2021).

Schmincke, I. (2020) 'Sexual politics from the right: attacks on gender, sexual diversity and sex education', in Dietze, G. and Roth, J. (Eds.) Right-Wing Populism and Gender: European Perspectives and Beyond. Transcript Verlag. 
Singer, A. (2012) Os sentidos do lulismo: reforma gradual e pacto conservador. Editora Companhia das Letras.

Singer, A. (2018) O lulismo em crise: um quebra-cabeça do período Dilma (2011-2016). Editora Companhia das Letras.

Skocpol, T. and Williamson, V. (2016) The Tea Party and the remaking of Republican conservatism. Oxford University Press.

Solano, E. (Ed.) (2018) O ódio como política: a reinvenção das direitas no Brasil. Boitempo Editorial.

Solano. E. (2019) 'A bolsonarização do Brasil', Documentos de Trabajo IELAT, Versión Digital, № 121, Abril. Available at https://ielat.com/wp-content/uploads/2019/03/DT_121_Esther-Solano-Gallego_Web_abril2019.pdf (Accessed: 29 April 2021)

Solano, E. (2020) ‘La politique, le marché et la morale selon l'extrême droite brésilienne', Le Brésil de Bolsonaro : le grand bond en arrière. Point de vue du Sud, Centre Tricontinental.

Szwako, J. (2014) 'O 'mau desempenho' de Lugo: gênero, religião e contramovimento na última destituição presidencial paraguaia', Opinião Pública, 20(1), pp. 132-155.

Tarrow, S. G. (2011) Power in movement: Social movements and contentious politics. Cambridge University Press.

The Economist (2009) "Brazil takes off", November 14th-20"t

Traverso, E. (2019) The new faces of fascism: Populism and the far right. Verso Books.

Tremblay, M., Paternotte, D. and Johnson, C. (Eds.) (2011) The lesbian and gay movement and the state: Comparative insights into a transformed relationship. Ashgate Publishing, Ltd.

Velasco Cruz, S., Kaysel, A.and Codas, G. (eds.) (2015) Direita, volver!: o retorno da direita e o ciclo político brasileiro. São Paulo, Editora Fundação Perseu Abramo.

Vencato, A. P., Silva, R. L. D. and Alvarenga, R. L. (2018) 'A educação e o presente instável: repercussões da categoria "ideologia de gênero" na construção do respeito às diferenças', Revista Psicologia Política, 18(43), pp. 587-598.

Vrydagh, F. (2020) Gagner les corps, les ccurs et les esprits : comprendre l'engagement dans le mouvement brésilien pro-destitution (2014-2016). PhD thesis. Université Libre de Bruxelles (ULB). Available at: https://dipot.ulb.ac.be/dspace/bitstream/2013/305496/3/TheseDifusionFV.pdf_(Accessed: 29 April 2021)

Weyland, K., Madrid, R., and Hunter, W. (Eds.) (2010) Leftist Governments in Latin America: Successes and Shortcomings. Cambridge: Cambridge University Press.

Wodak, R. (2015) The politics of fear: What right-wing populist discourses mean. Sage.

Žižek, S. (2015) O ano em que sonhamos perigosamente. Boitempo Editorial. 